\title{
Analysis of Views on Objective of Colleges' Ideological and Political Education based on Conversion from Course Education to Cultural Identity
}

\author{
Sumin Song ${ }^{1}$, Zhaoping Zhang $^{1}$, Xiaoxia Feng ${ }^{1}$ \\ ${ }^{1}$ Xingtai University, Xingtai, 054001, China
}

Keywords: Course education. Cultural identity. Course education. Ideological and political education

\begin{abstract}
Ideological and political education is the fine tradition that Chinese Communist Party has stuck to all the time and acts as a key which keeps core status and leadership of Chinese Communist Party in the field of social ideology. Thus, the country has been paying much attention to ideological and political education work. Currently, global situation is increasingly numerous and complicated. Besides, China has insisted on Reform and Opening-up for a long time and persisted in 'bring in' and 'go global' strategies. Undoubtedly, social culture will show a diversified and complicated situation. College students face with challenges of value orientation, so it is obvious that transition of colleges' ideological and political education has become an urgent affair.
\end{abstract}

\section{Introduction}

With social development, all aspects of the country encounter profound changes, reform can be seen everywhere, as well as social ideology, economic interest and pattern vary as well. The society is staying in a transformation period, so educational concept should advance with the times and keep up with pace of reform. When ideological and political education of colleges, which develops under a diversified background, faces with impacts of various cultures, it has been an inevitable choice to change teaching methods, i.e., converting them from course education to cultural identity. This is just the main content that this thesis will discuss.

\section{Basic connotation of ideological and political education}

The academic world has several different definitions of ideological and political education. In detail, the teacher Su Zhenfang defines ideological and political education as ideological and political education is the social behavior that some social classes or political groups apply impacts of ideology to people purposefully to realize some political objectives, change people's thoughts and guide people's actions'. This definition emphasizes practical guiding effect of ideological and political education. After comparing several concepts, it is concluded that ideological and political education involves that teachers intervene with students' ideology, political views and moral ideas by organized, purposeful and planned methods to some extent in order to make students form ideological and political characters that accord with social demands. Largely, ideological and political education of colleges reflects interests of ruling class. Range of ideological and political education includes internalization and externalization. Internalization means students accept political ideals, moral requirements and ideological standards required by the society under intervention of teachers or other educational factors, covert them into their own subjective initiative consciousness by absorption and form their own morality. Externalization just means students change subjective consciousness that they form by education into practical actions, express it via behaviors and develop this kind of behavioral patterns into habits. 


\section{Basic connotation of cultural identity}

Formation and development of identity has close relationship with its cultural and historical tradition. It can be said that they can rarely get rid of influence of culture and culture is an important element which cannot be separated for researches on identity. Cultural identity is a consensus and identity people reach in the aspect of a culture and acts as affirmation for basic value of the nation and the country, which people form gradually after long-term common life in a certain community. In another word, cultural identity is established based on human beings' social attribute and cultural attribute. When globalization is increasingly enhanced nowadays, cultural identity shows its powerful strength and serves as a basis on which national spirit can be coagulated. Now, it even becomes one of the important factors of competition about a country's comprehensive strength. Cultural identity is featured by 'self-identity'. Besides, cultural identity is a sense of intentionality, i.e., a certain kind of cultural identity will occur under the situation that several cultures impact one another. For instance, Spiral of Silence in communication science states people always choose to follow a powerful sound when they encounter different sounds so that weak strength will become more and more silent and approach powerful strength gradually. However, cultural identity does not advocate all kinds of different cultures contend against one another definitely. Thus, we can neither make cultural identity be opposite to globalization nor allow traditional culture contend against modern culture.

\section{General situations about contemporary college students’ cultural identity}

Contemporary college students stay in a period when the era is reformed and experience emergence of various high-tech products and popularization of internet. They are also a group that can master advanced techniques easily, have active thinking and tend to accept new things easily. Thus, the cultural impact they face with is quite fierce. With infiltration of western culture, contemporary students are confused when they treat traditional culture of our nation and even patriotism and national mission. Under the historical background of Reform and Opening-up, essence of traditional culture that we have inherited for several thousand years is being forgotten gradually. Under the condition of cultural diversification, deviation appears in many college students' value orientation. As a result, egoism runs wild and moral ideas are completely forgotten by such students. In addition, they excessively emphasize realization of personal value, ignore social value and have extremely strong utilitarian. When facing with invasion of foreign culture, a large number of students are affected by slogans like western democracy and human rights. In consequence, the phenomenon that they doubt local collectivism appears. Such students deem that western countries are more open and more democratic, completely ignore democracy of some western countries is established based on money and lack independent discernment and ability of judgment. In addition, contemporary students also face with the problem with respect to how to treat mainstream culture and non-mainstream culture. China is staying at the primary stage of socialism, the phenomenon that the good and bad are intermingled in cultural market is inevitable and non-mainstream culture has chances to survive, which makes some young students suffer corrosion of bad culture. These current situations, which appear in the group of college students who are future constructors of our society, clearly show that there are some problems in ideological and political education of colleges, which must be solved immediately.

\section{Relationship between ideological and political education of colleges and cultural identity}

Ideological and political education is a teaching activity that educators carry out behavior norms for students' ideological lines and moral rules by organized and planning methods. Ideological and political education not only implements holistic education for students but also standardizes students' behaviors overall.

Cultural identity has its profound connotation. Cultural concept, thinking mode and behavioral pattern contained by cultural identity show a person's value and value orientation to some extent and 
directly affect a person's world outlook, view of life and emotional tendency. Strength of cultural identity is reflection of national cohesion and it is powerful support for prosperity of the country and national unity.

Traditional ideological and political education pays much attention to course education so that teachers impart textbook knowledge to students in the whole class, ignores the degree to which students recognize opinions in textbooks and ideas that teachers impart in class and neglects significant impacts of cultural identity on ideological and political education course. Just like the situation that a doctor who does not have skillful medical skill can only cure symptoms instead of diseases and even delay the opportunity of patients' treatment, excessive emphasis of course education will cause the foregoing impacts as well. Psychologists used to analyze classical cases about attitude changes and found that attitude changes were reflected by three levels, i.e., compliance, identity and internalization. Specifically, identity can be rebuilt by using acquired impacts to intervene with and guide students' ideological mechanism purposefully. Therefore, to realize people-oriented original intention, ideological and political education must realize the huge role that culture identity plays in views on the objective of ideological and political education at colleges.

\section{Necessity to change colleges' ideological and political education from course education to cultural identity and significance}

\section{Necessity}

In the informationalized society, network brings earth-shaking changes to people's cultural life, and diversification of information, speediness of propagation speed and guiding role of internet public opinions affect student groups at colleges deeply. This is decided by students' features. First of all, college students not only have strong thirst for knowledge and good receptivity but also are staying in the period when they absorb various opinions and knowledge from all aspects widely. Secondly, input of diversified culture, especially western culture, has some covert effect, i.e., what is hidden under the appearance of cultural output is social consciousness and value form of capitalism. In addition, we cannot judge some thoughts are positive or negative in a short period. As a result, it is no doubt that ideological mechanism of student groups, who walk from immaturity to a mature period under unconscious influence, will be affected. Then, some behaviors that deviate from socialist core value system, such as following the trend, idolization and individualism, appear. Under the wind vane of freedom of speech, many people's thoughts are changing sharply. After long-term accumulation, hidden danger will be formed undoubtedly. For instance, current humanity emphasizes individualism increasingly. Under the circumstance, it is unworkable to carry out ideological and political education for college students only by course education. Under an ideal situation, the effect that symptoms are cured can be achieved. However, a worse situation may be that it will even trigger students' antipathy. Thus, it is quite important to improve degree of students' cultural identity at this time. Hence, conversion from course education to cultural identity is extremely urgent.

\section{Significance}

Ideological and political education of colleges also has some hysteretic nature at present. College students are future constructers and successors of our country, whose quality and ability will have significant impacts on future development of China. To improve college students' political accomplishment, ideological and political education must hold powerful effectiveness and pertinence. Under the situation that domestic and foreign situations change sharply, ideological and political education should advance with the times to a larger extent, be good at mastering trends of the era, analyze new ideological trends effectively, enhance education about Chinese nation's traditional culture, inherit our several thousand years' profound cultural deposits, strengthen humanistic education and build students' characters harmoniously and effectively when it attaches importance to cultivation of theoretical knowledge. The view on the objective that ideological and political education is changed from course education to cultural identity strengthens students' identity for mainstream culture at some height to make them have confidence in socialism, own fighting will to construct socialism with Chinese characteristics and hold profound faith in communism. 


\section{How can we realize conversion of colleges' ideological and political education from course education to cultural identity}

\section{Principles of the conversion from course education to cultural identity}

Insisting on correct guiding thoughts all the time

'Culture' is a topic with lasting charm and its definitions are diversified. In detail, different fields have different concepts about it. However, Marx the great tutor of proletariat summarized cultural nature in his works: 'Culture is a product of human beings' production practice in essence. People do work consciously, create a world of human beings and make natural world have significance of people simultaneously. This is meaning of culture'. People play a dominant role in cultural system, so realization of people's value and development situations of personality are important standards by which development of cultural identity is evaluated. For China a country staying in the transformation period, cultural identity must be the same as targets and directions towards which socialist culture with Chinese characteristics is built. In order to ensure correctness and advancement of cultural identity, it is essential to insist on correct guiding ideology firmly, use Marxism-Leninism, Mao Zedong Thought, Deng Xiaoping Theory, 'Three Represents Theory' and Socialist Concept of Honor and Disgrace as guidance, and establish correct ideals and conviction. Primarily, cultural identity should ensure guiding ideology is uniform and direction are clear rather than implement diversification of guiding ideology, which does not conflict with avocation of cultural diversification. The reason for this is that we cannot solidify cultural form or ignore ideology of cultural problems.

\section{Cultural identity should insist on correct cultural value guidance}

Cultural values existing in Chinese society at present tend to be diversified. Actually, this is an expression of social progress but does not mean this is not a good thing. The key lies in what kind of insight we use to analyze such a current situation. For instance, when foreign cultural value and local cultural value collide with each other, there will be some promoting effect on local culture definitely to some extent and then update of values will be promoted. Under the situation that diversification of cultural value is envisaged, the key problem lies in which cultural value people will choose as a dominant cultural value when they face numerous cultural values. It is worth mentioning that cultural identity of China must insist on regarding socialist cultural value as orientation, which is decided by our state system, regime and situations of social reality.

Cultural identity must insist on observing problems from a macroscopical perspective

Cultural identity is established on powerful cultural front. Guarantee can be provided for improvement in sense of cultural identity only when advanced mainstream culture and elite culture are built constantly based on excellent traditional culture of the national and essence of various cultures are absorbed continuously. At the same time, we must not ignore mass culture that is different elite culture and master development direction of mass culture because mass culture also has powerful effect on students' quality when network media develops rapidly nowadays.

Specific measures used for conversion from course education to cultural identity

Enhancing interaction and communication between teachers and students

Teachers should master guiding ideology of the Party well in ideological and political education, exert its dominant role in teaching process sufficiently, communicate with students frequently, combine with their practical situations and use their cultural connotation to influence students and enhance students' sense of cultural identity by communication and interactions.

Taking all-inclusive attitude in the teaching process and learning widely from others' strong points

Teachers should dare to face with the reality and the trend of cultural diversification in ideological and political education work, analyze impacts of various cultures on students clearly and accurately and understand essence of cultural identity really. Only in this way can they intervene with students in the aspect of cultural identity and realize the best teaching effect in the teaching process.

\section{Strengthening construction of cultural environment in campus}

It is necessary to build humanity atmosphere in campus consciously and ask students to take part in each link actively by recessive education to make students be influenced by Chinese traditional 
culture, enhance their sense of identity for traditional culture of Chinese nation and cultivate their national spirit.

\section{Conclusion}

In order to cope with challenges of economic globalization, society informatization and cultural diversity, ideological and political education, an important component of higher education, undertakes the arduous mission that it must cultivate contemporary college students' socialist core values. Colleges should treat problems about transition of ideological and political education by developing insight and finish the target that ideological and political education at colleges is converted from course education to cultural identity on the premise that both quality and quantity are ensured.

\section{Reference}

[1] Tian Yuting: Views on the Transformation of Higher Vocational Ideological and Political Education Goal from Curriculum Education to Cultural Identity, The Science Education Article Cultures, 2013(8).

[2] Liang Yuanhai: Researches on Views on the Transformation of Higher Vocational Ideological and Political Education Goal from Curriculum Education to Cultural Identity, Guangxi Social Sciences, 2012(2).

[3] Su Zhenfang: On Role of Cultural Identity in Ideological and Political Education, Ideological and Political Education Research, 2011(5).

[4] Wang Yanhua and Sun Li: Impacts of Cultural Identity on Implicit Formation of College Students' Thoughts and Educational Countermeasures, Ideological and Political Education Research, 2013(2).

[5] Lu Quanxin and Li Hong: College Students' Cultural Identity Crisis and Ideological and Political Education, Journal of Changchun University of Science and Technology (Social Science Edition), 2013(10).

[6] Liang Jianmei: Present Situation of the Effectiveness of the Ideological and Political Education of College and the Strategies [D]. Southwest University, 2007. 